\title{
Estimation of Some Heavy Metals in Polluted Well Water and Mercury Accumulation in Broiler Organs
}

\author{
Hussein Khamis Hussein ${ }^{1,2^{*}}$, Osama Abdullah Abu-Zinadah ${ }^{2}$, Haddad Abdulsameih EL- \\ Rabey $^{3}$ and Mohammed Fareez Meerasahib ${ }^{3}$ \\ ${ }^{I}$ Department of Zoology; Faculty of Science; Alexandria University; Alexandria - Egypt. ${ }^{2}$ Department of Biological \\ Sciences; Faculty of Science; King Abdulaziz University. ${ }^{3}$ Department of Biochemistry; Faculty of Science; King \\ Abdulaziz University - Saudi Arabia
}

\begin{abstract}
The aim of this study was to investigate the relationship between the concentrations of heavy metals in well water and bioaccumulation of the most abundant metals in chicken tissues in some areas in the province of Mecca Almokaramah, Saudi Arabia. Among the heavy metals (Cd, $\mathrm{Zn}, \mathrm{Cr}, \mathrm{Mn}, \mathrm{Cu} \mathrm{Hg}, \mathrm{Pb}$ and $\mathrm{Ni}$ ) studied, mercury ( $\mathrm{Hg}$ ) revealed highest in concentration in well waters. The concentration of mercury in the ground water, beside in liver, kidney, muscle and blood samples of ten chickens from each of four poultry-production farms were estimated using atomic absorption spectrophotometer. The results showed that the kidney followed by liver had the highest bioaccumulation of mercury in all farm samples. The level of mercury in the ground water was 7.06 $\mathrm{g} / \mathrm{L}$. The relationship between mercury accumulation levels in the kidney and those in the liver tissues were proportionally correlated and altered with elevation in the antioxidant enzyme activities such as AST and ALT. These elevated enzymatic activities were induced by the level of toxicity. There was a significant elevation in the level of liver and kidney malondialdhyde (MDA), while the activities of antioxidant enzymes superoxide dismutase and catalase (SOD and CAT) were significantly decreased. Biochemical observations were supplemented by histopathological examination of liver and kidney sections.
\end{abstract}

Key words: Environmental toxicology, ground water, heavy metals, mercury, bioaccumulation- chicken histopathology

\section{INTRODUCTION}

Water pollution is the contamination of water bodies (e.g. lakes, rivers, oceans and groundwater). Water pollution occurs when pollutants are discharged directly or indirectly into the water bodies without adequate treatment to remove the harmful compounds. Water pollution affects the animals and other organisms living in these bodies of water; and, in almost all cases the effect is damaging not only to individual species and populations, but also to the natural biological communities (Mapanda et al. 2005; Anne et al. 2007).

Heavy or toxic metals are trace metals with a density at least five times that of water. As such, they are stable elements (meaning they cannot be metabolized by the body) and bio-accumulative (passed up the food chain to the humans). These heavy metals include: mercury, nickel, lead, arsenic, cadmium, aluminum, platinum, and copper (the metallic form versus the ionic form

*Author for correspondence: ahssan555@yahoo.com 
required by the body). Heavy metals have no function in the body and can be highly toxic (Mohammad et al. 2010).

The rate of urbanization and industrialization has been in the increase for the last two decades in Saudi Arabia. Besides many problems associated with such social changes, the pollution is considered to be a major concern for the health of the nation. Among the numerous types of environmental pollutions that constitute as a danger to humanity, the contamination of food chain appears to be a growing threat that requires immediate attention and action. (Khan et al. 1996; Bachman et al. 2002; Anne et al. 2007; Mohammad et al. 2010).

Most heavy metals tend to be associated with sulphar in protein (Rossi and Santaroni 1976). The heavy metals content of streams, lakes and rivers did not normally exceed $0.1 \mathrm{ppm}$ although some water sources located near different heavy metals deposits might contain mixed amounts up to 80 ppm (Wershow 1970; Bachman et al. 2002). Limited data is available for the concentration of heavy metals in rain -water and snow. Manahan (1989) reported that most notorious mercury compounds (for example) in the environment are mono-methyl mercury salts and diethyl mercury salts which are water soluble.

The contaminated water with metals is the route of health hazards in the mankind human and animals. Among various pollutants in the environment, heavy metals are directly related to diseases in humans. Although it is difficult to classify the trace metal into essential and toxic groups, yet it is a well known fact that an essential metal becomes toxic at sufficiently high intakes (Khurshid and Qureshi 1984; Harter et al. 2002; Anne et al. 2007; Akbar Jan et al. 2010).

Lead may enter the environment during the mining, smelting, refining, and manufacturing processes and by the use of lead containing products. Lead intake occurs from the consumption of whisky, fruit juices, food stored in lead lined containers, cosmetics, cigarettes and motor vehicle exhaust etc (Harter et al. 2002; Aradhi et al. 2009). Excess lead can cause serious damage to the brain, kidneys, nervous system and red blood cells. Young children, infants and fetuses are particularly vulnerable to lead poisoning than the adult. According to the US Environment Protection Agency (EPA) says that lead may be implicated in causing leukemia (Anonymous 2002).
Zinc is essential for the normal functioning of the cells; including protein synthesis, carbohydrate metabolism, cell growth and cell division (Saeed 1998). However, if $\mathrm{Zn}$ concentration in the air is over $15 \mathrm{mg} / \mathrm{m} 3$, "metal fume fever" may result, which causes fever, depression, malaise, cough, vomiting, salivation and headache. cadmium replaces $\mathrm{Zn}$, in many enzymes. Therefore, a higher amount of $\mathrm{Zn}$ is required to overcome the toxic effects of cadmium (Khan et al. 1990).

High level of tissue concentration of iron causes increased risk of myocardial infarction (Harvey and Champe 1994) and high or low level of magnesium causes kidney failure and heart problems. High level of calcium is responsible for thirst, increased volume of urine, muscle fatigue, poor mental concentration and formation of kidney stones (Saeed 1998).

Water pollution with mercury is one of the major problems confronting the health officials everywhere. Mercury is a widespread environmental and industrial pollutant, which induces severe alterations in the tissues (Timbrell 1982; Manahan 1989; Lund et al. 1993; Mahboob et al. 2001; Sener et al. 2007), causes numerous neurological abnormalities (Kingman et al. 2005; Auger et al. 2005) and produces peripheral neuropathy (Boyd et al. 2000; Chuu et al. 2007) in the experimental animals and human beings.

Mercury poisoning can result from the inhalation, ingestion, or absorption through the skin and may be highly toxic and corrosive once absorbed into blood stream. Furthermore, it combines with proteins in the plasma or enters the red blood cells but does not readily pass into the brain or fetus and instead, may enter other body organs (El-Shenawy and Hassan 2008). The liver is a major site of metabolism for the mercury and it can accumulate in the liver resulting in severe hepatic damages. Previous studies have revealed that $\mathrm{HgCl}_{2}$ caused histopathological and ultrastructural lesions in the liver evidenced by periportal fatty degeneration and cell necrosis. Schurz et al. (2000) reported that DNA was a vital molecule in the cell activities and was the main target for $\mathrm{HgCl}_{2}$-induced cell injuries.

This study is a surveyed the heavy metals pathway from the environment through ground water to chicken in some particular areas in the province of Mecca Almokaramah where poultry farms were established. This study endeavored to measure these metals as environmental pollutants in the ground water, and investigated the 
bioaccumulation of mercury residues (as one of the major concentrated heavy metals) in chicken tissues of major poultry farms. To date no such studies have been conducted in this area where the chicken consumers have been on the increase. The outcome of this study might help in taking precautionary steps in monitoring the metal contamination in the ground water and to advice the authorities of the health impact that might have in Jeddah population as consumers.

\section{MATERIALS AND METHODS}

This study was carried out on four farms of poultry production located at four sites in the province of Mecca Almokaramah, Saudi Arabia. The first farm (A) was located in Om Al-Jood area, $150 \mathrm{Km}$ east of Jeddah governorate. The second farm (B) was located in Hada El-Sham area, $80 \mathrm{~km}$ east north Jeddah; the third one (C) in Al-Wazeeria region, $60 \mathrm{~km}$ east south Jeddah and the fourth one was Al-Fakeih poultry farm (D) in Jeddah governorate, which acted as a control group. The first three farms, A, B and C mainly depended on the ground water and regularly used the water from separate wells I, II and III respectively, while the fourth farm (D) was regularly used the healthy pure drinking water source (IV). The management of the four farms was identical, except the water source. The water samples were collected in clean glass bottles for chemical analysis according to APHA (1995).

The qualitative determination of cadmium $(\mathrm{Cd})$, zinc $(\mathrm{Zn})$, chromium $(\mathrm{Cr})$, magnesium $(\mathrm{Mn})$, copper $(\mathrm{Cu})$, mercury $(\mathrm{Hg})$, lead $(\mathrm{Pb})$ and nickel (Ni) were carried out using Flameless Atomic Absorption Spectrophotometer (Perkin Elmer 2380, U.S.A.). The actual representative concentration (ppm) of the most abundant heavy metal was determined per source. Precautions were taken to avoid the contamination during the sample collection.

The domestic white farm chickens (Gallus domesticus) were used in this study. Ten chickens, six weeks old, were chosen from each farm and slaughtered. Liver, kidneys, muscles and blood were taken to determine the mercury residues. Mercury was also determined in the tissue samples by flameless atomic absorption spectrophotometer equipped with a deuterium arc background corrector.
Serum biochemical assay and estimation of MDA, SOD, CAT in liver and kidney tissues:

Serum enzymes aspartate aminotransferase (AST) and serum glutamate pyruvate transaminase (ALT) were determined according to Reitman and Frankel (1957). Liver and kidney samples were dissected and washed immediately with ice cold saline to remove as much blood as possible. Each tested tissue homogenates $(5 \% \mathrm{w} / \mathrm{v})$ were prepared in cold $50 \mathrm{mM}$ potassium phosphate buffer $(\mathrm{pH}$ 7.4) using glass homogenizer in ice. The cell debris was removed by centrifugation at $5000 \mathrm{rpm}$ for 15 at $40^{\circ} \mathrm{C}$. The supernatant was used for the estimation of malondialdehyde (MDA) (Yagi and Rastogi 1979), superoxide dismutase (SOD) (Kakkar et al. 1972) and catalase (CAT) (Smna, 1972) levels.

\section{Histopathological studies}

The target organs (liver and kidney) tissues were dissected and fixed in 10\% formalin, dehydrated in gradual ethanol (50-99\%), cleared in xylene, and embedded in paraffin. Sections were prepared and then stained with hematoxylin and eosin dye for the microscopic investigation.

\section{Statistical analysis}

Statistical analysis was performed on a PC using SPSS, V.13, (special package for social sciences). Data are presented as the arithmetic mean \pm S.D., The difference among the means has been analyzed by one way ANOVA followed by student $t$ test. A value of $P<0.05$ was considered as statistically significant.

\section{RESULTS}

Table 1 shows the mean concentration (ppm) of cadmium, zinc, chromium, magnesium, copper, mercury, lead and nickel in (A-C). There were significant variations between sites $(P<0.05)$. The mean concentrations (ppm) of heavy metals ranged from 0.001 to 0.003 for $\mathrm{Cd}, 0.09$ to 0.23 for $\mathrm{Zn}, 0.03$ to 0.15 for $\mathrm{Cr}, 0.12$ to 0.16 for $\mathrm{Mn}, 0.11$ to 0.27 for $\mathrm{Cu}, 0.38$ to 7.34 for $\mathrm{Hg}, 0.06$ to 0.10 for $\mathrm{Pb}$, and 0.04 to 0.06 for Ni. (Table 1). Mercury was highest at farm $\mathrm{A}$ and $\mathrm{B}$, which received water from the wells I and II, the levels which exceeds the permissible metal limits of drinking water (6.78 to $7.34 \mathrm{ppm}$ with a mean of $7.06 \mathrm{ppm}$; Table, 2). The samples from $\mathrm{C}$ and $\mathrm{D}$ showed $\mathrm{Hg}$ concentration lying in the permissible metal limits 
of drinking water (WHO, 1980, 1984). For this reason the residual quantities of mercury, which were the most abundant heavy metals in the analyzed wells water samples were estimated in different chicken tissues to find the bioaccumulation of this toxic metal in the tissues and blood of the chicken in poultry farms supplied with this water.

The highest $\mathrm{Hg}$ concentrations were detected in the kidney, which is considered the main target organ followed by the liver. The residual quantities of mercury in the liver tissues ranged from 110 to $179 \mu \mathrm{g} / 100 \mathrm{~g}$ with a mean of 143.4 $\mu \mathrm{g} / 100 \mathrm{~g}$ in 8 cases from farm $\mathrm{A}$, while the rest revealed undetectable amount of mercury; 123 to $183 \mu \mathrm{g} / 100 \mathrm{~g}$ with a mean of $137.4 \mu \mathrm{g} / 100 \mathrm{~g}$ in 9 cases from farm $\mathrm{B}$, a mean of $132 \mu \mathrm{g} / 100 \mathrm{~g}$ in 4 cases from farm $C$; and a mean of $117.2 \mu \mathrm{g} / 100 \mathrm{~g}$ in 4 cases from farm $D$. The rest of the samples revealed undetectable mercury levels (Table 2).

Table 1 - Heavy metal concentrations (ppm) in water sources supplying the chicken farms in different the study sites.

\begin{tabular}{|c|c|c|c|c|c|c|c|c|c|}
\hline \multirow{2}{*}{ Farm } & \multirow{2}{*}{ Level } & \multicolumn{8}{|c|}{ Concentrations of heavy metals in farm water (ppm) } \\
\hline & & $\mathbf{C d}$ & $\mathrm{Zn}$ & $\mathrm{Cr}$ & Mn & $\mathrm{Cu}$ & $\mathrm{Hg}$ & $\mathbf{P b}$ & $\mathbf{N i}$ \\
\hline \multirow{3}{*}{ A } & Mean & 0.002 & 0.09 & 0.03 & 0.12 & 0.11 & 7.34 & 0.10 & 0.05 \\
\hline & Median & 0.001 & 0.07 & 0.02 & 0.09 & 0.05 & 4.22 & 0.06 & 0.03 \\
\hline & Range & $0.00-0.002$ & $0.00-0.12$ & $0.00-0.12$ & $0.00-0.18$ & $0.00-0.84$ & 3.09-9.01 & $0.00-0.37$ & $0.00-0.09$ \\
\hline \multirow{3}{*}{ B } & Mean & 0.003 & 0.17 & 0.09 & 0.14 & 0.15 & 6.78 & 0.06 & 0.04 \\
\hline & Median & 0.001 & 0.09 & 0.06 & 0.08 & 0.03 & 3.74 & 0.04 & 0.02 \\
\hline & Range & ND-0.004 & $0.02-0.25$ & $0.00-0.10$ & $0.00-0.28$ & $0.00-0.44$ & $2.99-8.22$ & $0.00-0.39$ & $0.00-0.07$ \\
\hline \multirow{3}{*}{$\mathrm{C}$} & Mean & 0.001 & 0.23 & 0.15 & 0.15 & 0.15 & 1.36 & 0.08 & 0.06 \\
\hline & Median & 0.002 & 0.15 & 0.13 & 0.10 & 0.11 & 1.21 & 0.05 & 0.04 \\
\hline & Range & ND-0.003 & $0.03-0.37$ & $0.00-0.27$ & $0.00-0.43$ & $0.00-0.53$ & $1.00-1.48$ & $0.00-0.25$ & $0.00-0.09$ \\
\hline \multirow{3}{*}{$\mathrm{D}$} & Mean & 0.002 & 0.20 & 0.06 & 0.16 & 0.27 & 0.38 & 0.07 & 0.05 \\
\hline & Median & 0.001 & 0.17 & 0.05 & 0.12 & 0.18 & 0.18 & 0.04 & 0.03 \\
\hline & Range & ND-0.004 & $0.02-0.27$ & $0.00-0.18$ & $0.00-0.33$ & $0.00-0.51$ & $0.00-0.41$ & $0.00-0.09$ & $0.00-0.6$ \\
\hline \multicolumn{2}{|c|}{$\begin{array}{l}\text { Permissible limits of } \\
\text { heavy metals }(\mathrm{ppm}) \text { in } \\
\text { water (WHO, 1984) }\end{array}$} & $0.00-0.005$ & $1.02-2.99$ & $0.00-1.20$ & $0.00-1.05$ & $0.00-1.00$ & $1.00-2.68$ & $0.00-0.50$ & $0.00-1.12$ \\
\hline
\end{tabular}

Table 2 - Relationship between the concentrations of mercury in various tissues of chickens (6 weeks old) and in the ground water in four different poultry farms in Mecca Al-Mokaramah Province.

\begin{tabular}{|c|c|c|c|c|c|c|c|c|c|c|c|c|c|}
\hline \multirow{2}{*}{$\begin{array}{c}\text { Well } \\
\text { No. }\end{array}$} & \multirow{2}{*}{$\begin{array}{l}\text { Mean Conc. } \\
\text { of Mercury } \\
\text { in well } \\
\text { water (ppm) }\end{array}$} & \multirow{2}{*}{ Farm } & \multirow[b]{2}{*}{ Organ } & \multicolumn{10}{|c|}{ Concentration of mercury in the collected samples $(\mu \mathrm{g} / 100 \mathrm{~g})$ wet weight } \\
\hline & & & & 1 & 2 & 3 & 4 & 5 & 6 & 7 & 8 & 9 & 10 \\
\hline \multirow{8}{*}{$\begin{array}{l}\text { I } \\
\text { and } \\
\text { II }\end{array}$} & \multirow{8}{*}{$7.06 \pm 1.4$} & \multirow{4}{*}{ A } & Liver & $110 \pm 3.37$ & $155 \pm 4.02$ & $126 \pm 3.89$ & $152 \pm 3.66$ & ND & $165 \pm 3.86$ & ND & $179 \pm 3.42$ & $143 \pm 2.75$ & $129 \pm 2.13$ \\
\hline & & & Kidney & $734 \pm 9.55$ & $508 \pm 5.72$ & $351 \pm 5.09$ & $646 \pm 7.41$ & $491 \pm 5.33$ & $410 \pm 4.22$ & -- & $516 \pm 4.76$ & $485 \pm 3.71$ & $561 \pm 4.76$ \\
\hline & & & Muscle & & -- & -- & -- & -- & -- & -- & -- & -- & -- \\
\hline & & & Blood & -- & -- & -- & -- & -- & -- & -- & -- & -- & -- \\
\hline & & \multirow{4}{*}{ B } & Liver & $183 \pm 3.76$ & $129 \pm 3.40$ & $136 \pm 3.09$ & $134 \pm 3.33$ & $160 \pm 2.15$ & ND & $131 \pm 2.11$ & $123 \pm 3.06$ & $135 \pm 2.13$ & $132 \pm 2.66$ \\
\hline & & & Kidney & $627 \pm 7.58$ & $484 \pm 4.11$ & $457 \pm 3.66$ & $645 \pm 6.03$ & $532 \pm 4.50$ & $616 \pm 7.11$ & $406 \pm 4.29$ & $505 \pm 3.35$ & ND & $645 \pm 6.55$ \\
\hline & & & Muscle & -- & -- & -- & -- & -- & -- & -- & -- & -- & -- \\
\hline & & & Blood & -- & -- & -- & -- & -- & -- & -- & -- & -- & -- \\
\hline \multirow{8}{*}{$\begin{array}{l}\text { III } \\
\text { and } \\
\text { IV }\end{array}$} & \multirow{8}{*}{$\begin{array}{c}\text { Not } \\
\text { detectable }\end{array}$} & \multirow{4}{*}{$\mathrm{C}$} & Liver & $154 \pm 3.75$ & $130 \pm 2.66$ & ND & ND & $141 \pm 2.34$ & -- & -- & $103 \pm 2.05$ & -- & -- \\
\hline & & & Kidney & $487 \pm 4.01$ & $542 \pm 4.64$ & $463 \pm 3.99$ & $504 \pm 5.22$ & -- & -- & -- & -- & -- & -- \\
\hline & & & Muscle & -- & -- & -- & -- & -- & -- & -- & -- & -- & -- \\
\hline & & & Blood & -- & -- & -- & -- & -- & -- & -- & -- & -- & -- \\
\hline & & \multirow{4}{*}{ D } & Liver & $100 \pm 2.12$ & -- & -- & $124 \pm 3.55$ & ND & $127 \pm 2.15$ & -- & $118 \pm 2.11$ & -- & -- \\
\hline & & & Kidney & -- & -- & -- & $457 \pm 4.41$ & $498 \pm 5.77$ & -- & -- & $437 \pm 4.44$ & -- & -- \\
\hline & & & Muscle & -- & -- & -- & -- & -- & -- & -- & -- & -- & -- \\
\hline & & & Blood & - - & -- & -- & -- & -- & -- & -- & -- & -- & -- \\
\hline
\end{tabular}

Data are expressed as $\mu \mathrm{g} / 100 \mathrm{~g}$ wet tissue as mean \pm S.E. of five samples from each individual, ND: Not detectable. 
The residual quantities of mercury, estimated in kidney tissues ranged from 351 to $734 \mu \mathrm{g} / 100 \mathrm{~g}$ with a mean of $542 \mu \mathrm{g} / 100 \mathrm{~g}$ in nine cases from farm A, 406 to $645 \mu \mathrm{g} / 100 \mathrm{~g}$ with a mean of 548.3 $\mu \mathrm{g} / 100 \mathrm{~g}$ in nine cases from farm B; a mean of 499 $\mu \mathrm{g} / 100 \mathrm{~g}$ in four detectable cases from farm $\mathrm{C}$; a mean of $464 \mu \mathrm{g} / 100 \mathrm{~g}$ in three detectable cases from farm D. The rest of the samples revealed undetectable (Table 2). All the examined blood and muscle samples showed concentrations below the detectable level.

Mercury contents in the liver and kidney were significantly elevated in all the samples collected from farms $\mathrm{A}$ and $\mathrm{B}$ than from farms $\mathrm{C}$ and $\mathrm{D}(\mathrm{P}$ $<0.001)$. The well water analysis in the four tested farms also clearly showed higher concentration of mercury in farms A and B than those from farms C and $\mathrm{D}$. This was accompanied by a significant increase in the concentration of mercury level in the kidney as well as in liver $(\mathrm{P}<0.01)$. The accumulation of mercury in kidney of all tested samples was highly significant $(\mathrm{P}<0.001)$ than those in the liver (Table 3).

Enzyme activities of liver and kidney of chickensof the three polluted well farms (A - C) and the control farm (D) are illustrated in Table 4. Serum AST and ALT were significantly increased in the three contaminated farms as compared to the control group $(\mathrm{P}<0.001)$. The elevated activities of serum AST and ALT were significantly reduced in the animal groups supplied with pure water (control). Supplying with well water I and II in farm A and B respectively showed significantly more enzyme activity $(P<0.001)$ than those supplied with well water III (Farm C). Results obtained also revealed an increase in the level of liver and kidney MDA in polluted water farm chickens groups compared to the control group. The activities of SOD and CAT were significantly reduced in the first two contaminated farms (farm $A$ and $B$ ), while they were significantly elevated near the normal values in the third group (farm C) or control group (farm D) of non-detected mercury levels.

The chicken liver of the farms A and B which were regularly supplied the water from the polluted wells I and II respectively showed massive fatty changes, necrosis, and broad infiltration of the lymphocytes (Figs. 1A, 1B). The histological architecture of the liver sections of the chickens supplied with undetectable mercury water well III (Fig. 1C) showed more or less normal patterns, with a mild degree of necrosis and slightly lymphocyte infiltration, almost comparable to those of the control group. The histological examination of liver sections of control animals (Fig. 1D) showed normal hepatic cells with well preserved cytoplasm prominent nucleus.

Table 3 - Means of mercury concentration in farm water $(\mathrm{ppm})$ and in organs $(\mu \mathrm{g} / 100 \mathrm{~g}$ wet weight).

\begin{tabular}{|c|c|c|c|c|c|c|}
\hline \multirow{2}{*}{$\begin{array}{c}\begin{array}{c}\text { Mean con. Of mercury } \\
\text { in farm water }\end{array} \\
\text { Farm }\end{array}$} & \multicolumn{3}{|c|}{$7.06 \pm 1.40$} & \multicolumn{3}{|c|}{ No detectable } \\
\hline & $\mathbf{A}$ & $\mathbf{B}$ & $\mathbf{A}+\mathbf{B}$ & $\mathbf{C}$ & D & $\mathrm{C}+\mathrm{D}$ \\
\hline $\begin{array}{l}\text { Mean of all liver } \\
\text { samples }\end{array}$ & $107.5 \pm 3.22$ & $126.0 \pm 3.08$ & $116.7 \pm 3.11$ & $044.0 \pm 1.42$ & $048.0 \pm 2.05$ & $046.0 \pm 1.66$ \\
\hline $\begin{array}{l}\text { Mean of all detectable } \\
\text { samples }\end{array}$ & $143.4 \pm 2.45$ & $137.4 \pm 2.18$ & $140.1 \pm 3.07$ & $132.0 \pm 2.33$ & $117.2 \pm 2.75$ & $123.7 \pm 2.82$ \\
\hline $\begin{array}{l}\text { Mean of all kidney } \\
\text { samples }\end{array}$ & $406.5 \pm 4.14$ & $456.9 \pm 3.67$ & $431.7 \pm 3.08$ & $166.3 \pm 2.41$ & $116.0 \pm 1.55$ & $141.0 \pm 3.72$ \\
\hline $\begin{array}{l}\text { Mean of all detectable } \\
\text { samples }\end{array}$ & $542.0 \pm 3.56$ & $548.3 \pm 5.11$ & $545.3 \pm 4.26$ & $499.0 \pm 3.87$ & $464.0 \pm 4.27$ & $484.0 \pm 4.23$ \\
\hline \multicolumn{7}{|c|}{ T - Test data } \\
\hline Farm & \multicolumn{2}{|l|}{ Organ } & Mean \pm S.E. & \multicolumn{2}{|l|}{ Value of $t$} & $\mathbf{P}$ \\
\hline \multirow{2}{*}{$(A+B)$} & Liver & & $140.1 \pm 3.07$ & \multirow{2}{*}{\multicolumn{2}{|c|}{194.392}} & \multirow{2}{*}{$<0.001$} \\
\hline & Kidney & & $545.3 \pm 4.26$ & & & \\
\hline \multirow{2}{*}{$(\mathrm{C}+\mathrm{D})$} & Liver & & $123.7 \pm 2.82$ & \multirow{2}{*}{\multicolumn{2}{|c|}{111.013}} & \multirow{2}{*}{$<0.001$} \\
\hline & Kidney & & $484.0 \pm 4.27$ & & & \\
\hline$(\mathrm{A}+\mathrm{B})+(\mathrm{B}+\mathrm{C})$ & Liver & & $131.9 \pm 3.74$ & 006.047 & & $>0.05$ \\
\hline$(\mathrm{A}+\mathrm{B})+(\mathrm{B}+\mathrm{C})$ & Kidney & & $514.6 \pm 5.12$ & 022.371 & & $<0.01$ \\
\hline
\end{tabular}

Insignificant difference $(\mathrm{P}>0.05)$; significant difference $(\mathrm{P}<0.01)$ and highly significant difference $(\mathrm{P}<0.001)$ 
Tabela 4 - Enzyme activities of liver and kidney of chickens of the control and three well polluted farms; superoxide dismutase (SOD), catalase (CAT), lipid peroxide product or Malendialdlyde (MDA) and serum aminotransferase enzymes (ALT and AST) of all studied groups (Mean \pm SD).

\begin{tabular}{|c|c|c|c|c|c|c|c|c|}
\hline \multirow{2}{*}{$\begin{array}{l}\text { Chicken group } \\
\text { parameter }\end{array}$} & \multicolumn{2}{|c|}{ Control (Farm D) } & \multicolumn{2}{|c|}{ Farm A } & \multicolumn{2}{|c|}{ Farm B } & \multicolumn{2}{|c|}{ Farm C } \\
\hline & Liver & Kidney & Liver & Kidney & Liver & Kidney & Liver & Kidney \\
\hline Serum ALT (IU/ml) & $36.9 \pm 4.49$ & $37.1 \pm 4.44$ & $57.8 \pm 7.91$ & $56.2 \pm 8.88$ & $45.8 \pm 6.99$ & $46.0 \pm 7.09$ & $39.9 \pm 4.99$ & $40.2 \pm 4.67$ \\
\hline $\mathrm{P}_{1 \text { Value }}$ & - & - & $\mathrm{P} \leq 0.001$ & $\mathrm{P} \leq 0.001$ & $\mathrm{P} \leq 0.001$ & $\mathrm{P} \leq 0.001$ & $\mathrm{P} \leq 0.001$ & $\mathrm{P} \leq 0.001$ \\
\hline $\mathrm{P}_{2}$ Value & - & - & - & - & $\mathrm{P} \leq 0.001$ & $\mathrm{P} \leq 0.001$ & $\mathrm{P} \leq 0.05$ & $\mathrm{P} \leq 0.05$ \\
\hline$P_{3}$ Value & - & - & - & - & - & - & $\mathrm{P} \leq 0.05$ & $\mathrm{P} \leq 0.05$ \\
\hline Serum AST(IU/ml) & $40.8 \pm 4.55$ & $41.1 \pm 4.49$ & $56.7 \pm 8.01$ & $55.2 \pm 7.99$ & $48.8 \pm 6.69$ & $49.1 \pm 7.007$ & $44.8 \pm 4.72$ & $43.9 \pm 4.32$ \\
\hline$P_{1 \text { Value }}$ & - & - & $\mathrm{P} \leq 0.001$ & $\mathrm{P} \leq 0.001$ & $\mathrm{P} \leq 0.001$ & $\mathrm{P} \leq 0.001$ & $\mathrm{P} \leq 0.001$ & $\mathrm{P} \leq 0.001$ \\
\hline$P_{2}$ Value & - & - & - & - & $\mathrm{P} \leq 0.001$ & $\mathrm{P} \leq 0.001$ & $\mathrm{P} \leq 0.05$ & $\mathrm{P} \leq 0.05$ \\
\hline $\mathrm{P}_{3}$ Value & - & - & - & - & - & - & $\mathrm{P} \leq 0.05$ & $\mathrm{P} \leq 0.05$ \\
\hline MDA (m mol/mg protein) & $2.33 \pm 0.16$ & $2.35 \pm 0.18$ & $3.21 \pm 0.55$ & $3.28 \pm 0.49$ & $2.98 \pm 0.23$ & $3.01 \pm 0.31$ & $2.56 \pm 0.32$ & $2.61 \pm 0.47$ \\
\hline $\mathrm{P}_{1 \text { Value }}$ & - & - & $\mathrm{P} \leq 0.001$ & $\mathrm{P} \leq 0.001$ & $\mathrm{P} \leq 0.001$ & $\mathrm{P} \leq 0.001$ & $\mathrm{P} \leq 0.001$ & $\mathrm{P} \leq 0.001$ \\
\hline $\mathrm{P}_{2 \text { Value }}$ & - & - & - & - & $\mathrm{P} \leq 0.001$ & $\mathrm{P} \leq 0.001$ & $\mathrm{P} \leq 0.01$ & $\mathrm{P} \leq 0.01$ \\
\hline $\mathrm{P}_{3}$ Value & - & - & - & - & - & - & $\mathrm{P} \leq 0.05$ & $\mathrm{P} \leq 0.05$ \\
\hline SOD (MU/mg protein) & $221.3 \pm 14.1$ & $224.1 \pm 13.8$ & $106.9 \pm 21.7$ & $110.2 \pm 2704$ & $203.3 \pm 23.8$ & $207.1 \pm 27.7$ & $187.7 \pm 23.3$ & $188.9 \pm 24$ \\
\hline $\mathrm{P}_{1 \text { Value }}$ & - & - & $\mathrm{P} \leq 0.001$ & $\mathrm{P} \leq 0.001$ & N.S. & N.S. & $\mathrm{P} \leq 0.001$ & $\mathrm{P} \leq 0.001$ \\
\hline $\mathrm{P}_{2 \text { Value }}$ & - & - & - & - & $\mathrm{P} \leq 0.001$ & $\mathrm{P} \leq 0.001$ & $\mathrm{P} \leq 0.01$ & $\mathrm{P} \leq 0.01$ \\
\hline$P_{3 \text { Value }}$ & - & - & - & - & - & - & $\mathrm{P} \leq 0.01$ & $\mathrm{P} \leq 0.01$ \\
\hline $\begin{array}{l}\mathrm{CAT}(\mathrm{n} \mathrm{mol} / \mathrm{min} / \mathrm{mg} \\
\text { protein) }\end{array}$ & $\begin{array}{c}9757.1 \pm \\
122.1\end{array}$ & $\begin{array}{c}9747.9 \pm \\
142.1\end{array}$ & $\begin{array}{c}2174.8 \pm \\
139.1\end{array}$ & $\begin{array}{c}2300.4 \pm \\
144.8\end{array}$ & $\begin{array}{c}8300.4 \pm \\
144.7\end{array}$ & $\begin{array}{c}8382.7 \pm \\
137.7\end{array}$ & $\begin{array}{c}3989.1 \pm \\
177.6\end{array}$ & $\begin{array}{c}4010.7 \pm \\
146.4\end{array}$ \\
\hline $\mathrm{P}_{1 \text { Value }}$ & - & - & $\mathrm{P} \leq 0.001$ & $\mathrm{P} \leq 0.001$ & N.S. & N.S. & $\mathrm{P} \leq 0.001$ & $\mathrm{P} \leq 0.001$ \\
\hline $\mathrm{P}_{2}$ Value & - & - & - & - & $\mathrm{P} \leq 0.001$ & $\mathrm{P} \leq 0.001$ & $\mathrm{P} \leq 0.01$ & $\mathrm{P} \leq 0.01$ \\
\hline $\mathrm{P}_{3 \text { Value }}$ & - & - & - & - & - & - & $\mathrm{P} \leq 0.05$ & $\mathrm{P} \leq 0.05$ \\
\hline
\end{tabular}
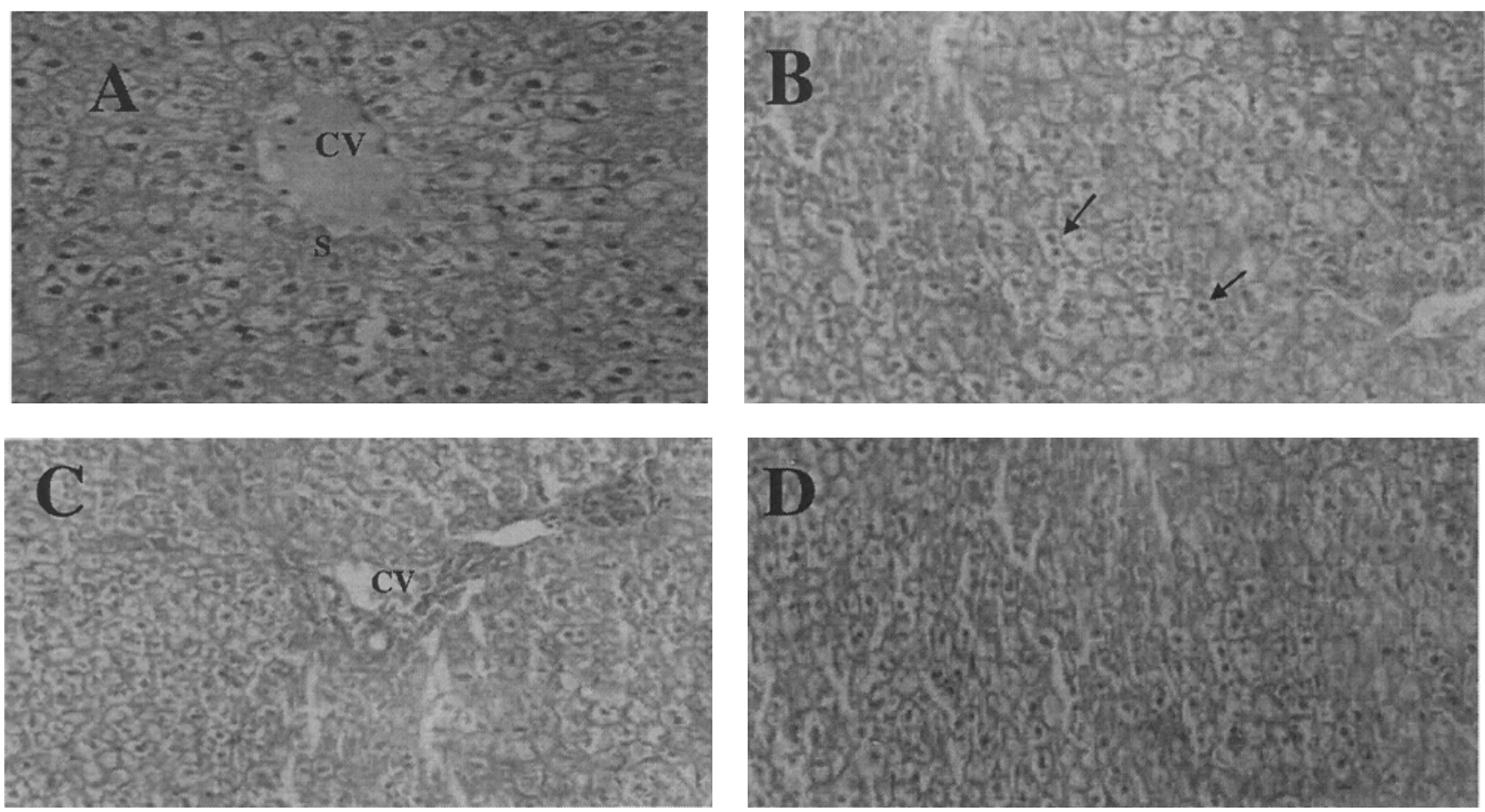

Figure 1 - (A) Hepatic tissues showing hepatic strands with necrosis around the central vein $(\mathrm{CV})$ leaving blood sinusoids (S) X 400, (B) hepatic tissues of farm 'B' group showing highly cellular necrosis (arrows) around the central veins X 250, (C) hepatic tissues of farm "C" showing degenerating central vein $(\mathrm{CV})$ and (D) hepatic tissues of farm 'D' showing clear regular hepatic strands X 250 (H\&E stains). 
The chicken kidneys of farms A and B which were regularly supplied the water from the polluted wells I and II respectively showed tissues with tubular epithelial damage, capillary proliferation certain degenerated uriniferous tubules and dilatation of Bowman's capsule (Figs. 2A and 2B).
The above pathological changes were disappeared in chickens supplied with undetectable mercury water well III (Fig. 2C). The histological examination of liver sections of the control animals (Fig. 2D) also showing normal renal tissues and normal uriniferous tubules and glomeruli.
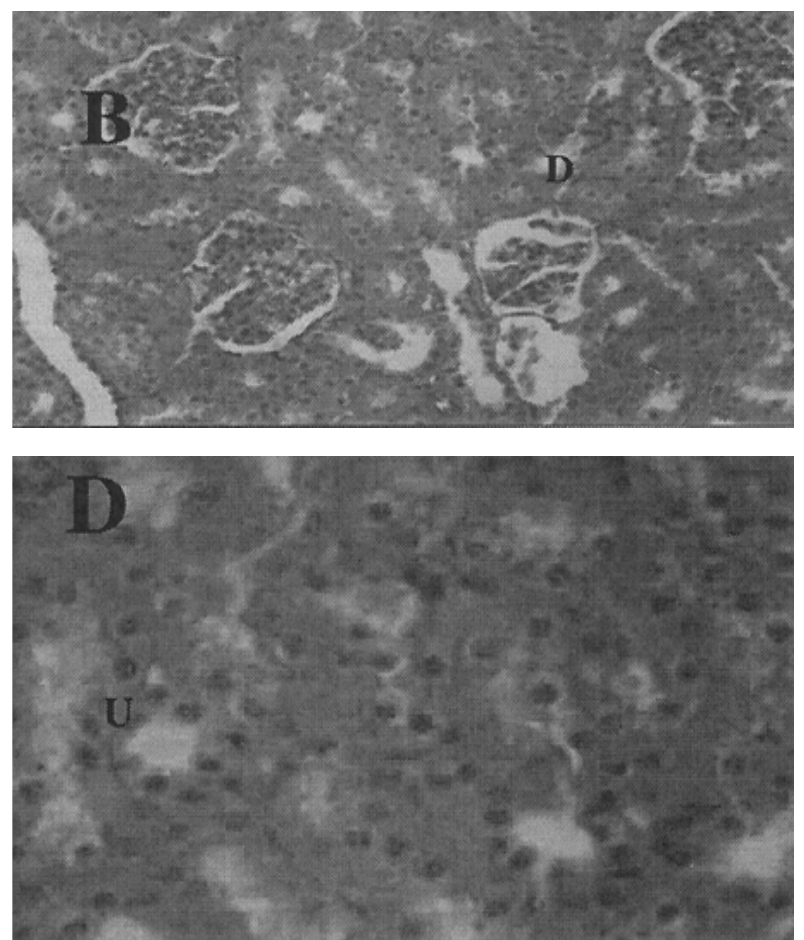

Figure 2 - (A)Renal tissues showing convoluted urineferous tubules (u) and glomeruli (G) X440, (B) renal tissues of farm "B" group showing certain degenerated urineferous tubules (D) $\mathrm{X}$ 440, (C) renal tissues of farm "C" showing dilatation of Bowman's capsule (DT) X 440, and (D) renal tissues of farm "D" showing normal renal structure with regulated nuclear arrangement of urineferous tubules (u) X 500 (H\&E stains).

\section{DISCUSSION}

Table 1 presented the mean concentration (ppm) of cadmium, zinc, chromium, magnesium, copper, mercury, lead and nickel in polluted well supplied farms (A-C) and healthy water supplied farm (D). Although the concentrations of these metals in ground water and fresh tap water lie within the permissible limits recommended by WHO (1984), yet the concentrations of mercury in polluted well water was considered highly significant increased than those of control healthy water and highly elevated than the recommended values by WHO (1984). Nearly similar findings were obtained by Dall Aglio (1968), Warshaw (1970), Zaki et al. (1994) and Abd El-Nasser et al. (1996), and by Youssef and Haleem (1999).
Limited data were available for concentrations of mercury in wells water. Dall Aglio (1968) measured 300 samples from natural water for mercury in Italy and found values in the range of 10-15 ppm. The present study showed undetectable mercury levels in 2 wells and 7.06 ppm in the other two wells. Similar results were reported by Wershaw (1970), who revealed that the mercury content of streams, lakes and rivers does not exceed $0.1 \mathrm{ppm}$ but some water sources located near mercury deposits may contain mercury up to $8.0 \mathrm{ppm}$. It is obvious that the examined water samples from wells I and II exceeded the permissible limits indicative of water pollution $(1.00-2.68 \mathrm{ppm})$ and water quality standard (WHO, 1984). 
The trace amounts of mercury detected in the liver, kidneys, muscle and blood tissues of chickens showed the current status and the background $\mathrm{Hg}$ concentrations in water supply the poultry farms. The detected $\mathrm{Hg}$ levels in chicken organs are in accordance with those reported by other authors (Pribilincov et al. 1997; Marettova et al. 2003; Cabanero et al. 2005).

Most mercury compounds of the contaminant water are inorganic form. Absorption of inorganic mercury compounds may be $15 \%$ or less (WHO, 1980), whereas methyl mercury is almost completely absorbed. Inorganic mercury compounds are rapidly accumulated in the kidney which is the main target organ for these compounds. Animal data indicate that the kidney accumulate the highest tissue concentration no matter what form of mercury is administrated (WHO, 1976). This opinion gets along with the present results which showed that the kidney followed by liver are the organs with the highest bioaccumulation of mercury in all farm samples. Similar results were previously reported by Manahan (1989), Lund et al. (1993), Mahboob et al. (2001), Sener et al. (2007).

Although the kidney tissue showed the highest concentration of mercury, its residue could not be detected in all samples which may be explained by uncertain and indirect nature of relationships calculated between the intake of mercury through water and levels of mercury in the indicator organs (WHO 1972; Manahan 1989; Pribilincov et al. 1997; El-Shenawy and Hassan 2008). Considerable individual variation around the average values of mercury residual have been noted, which must be taken into account in the estimation of risk in exposed populations.

Regarding to the presence to the presence of mercury in the kidney and/ or liver in chicken supplied by undetectable mercury level wellwater, WHO (1972) reported that the rate of mercury accumulation is independent of the intake level and that of toxic level would be reached eventually, even at a very low intake level. Such conclusion is in agreement with that of Cabanero et al. (2005). It is evident therefore, that even very small concentration of mercury in the environment may constitute eventual toxicological hazard.

In the present study, alteration in the normal levels of various serum biochemical parameters accompanied by the histopathological necrosis and degenerative changes in the liver and kidney tissue were the main toxic effects observed in the chickens drinking polluted water. In fact, some physiological changes has been accompanies with mercury toxicities. Such decrease in body weight gain of chicken due to mercury exposure has been reported earlier also (Marettova et al. 2003). Furthermore, it has also been reported that mercury exposure increased the activities of AST and qualitative vascular degenerative of kidney tissues and necrotic changes were also observed in the liver of chickens (Zraly et al. 2008). These observations are clearly in agreement with the present findings.

Serum AST and ALT activities were used as a marker of tissue damage. Mercury toxicity's produces tissue damage due to its toxic metabolites (Sharma et al. 2002). The toxic metabolite free radical is produced by cytochrome p450 which further reacts with oxygen to produce trichloromethyl peroxy radicals (Borg et al. 2003). These radicals bind covalently with the macromolecule and cause peroxidative degradation of lipid membranes of the liver and kidney. Increased lipid peroxidation under pollution conditions can be due to increased oxidative stress in the cell as a result of depletion of antioxidant scavenger systems. Associated with the changes in lipid peroxidation the affected tissues showed decreased activities of key antioxidants SOD and CAT and increase MDA which play an important role in scavenging the toxic intermediate of incomplete oxidation. SOD and CAT are the two major scavenging enzymes that remove toxic free radicals in vivo. Previous studies have reported that the activity of SOD is low after mercury toxicities (Sobutskii et al. 2007) who measured biochemical indexes of blood after low doses of mercury exposures which come in agreement with our results.

Elevation in the activity of serum AST and ALT, the cytoplasmic enzymes, indicates for necrotic lesions in the liver and tissue degeneration of the kidney, while a decrease in serum SOD and CAT levels indicates for no congestion or cholestasis (Lysenko 2000; Borg et al. 2003; Cabanero et al. 2005). These researchers reported that chickens treated with $\mathrm{HgCl}_{2}$ showed significant elevations in serum glutamate oxaloacetate transaminase (SGOT) and serum glutamate pyruvate transaminase (SGPT) activities, whereas a significant decline in the SOD and CAT activities and also come in agreement and confirm our results. 
The present study also shows that chickens supplied with mercury polluted water have elevated levels of serum AST and ALT, whereas a reduced level of SOD and CAT as compared to the control group, indicating clearly that our results are in agreement with other studies on chickens (Borg et al. 2003; Cabanero et al. 2005; Zraly et al. 2008).

On the other hand, in non-chicken model also (teleost fish), Sastry and Sharma (1980) reported that SOD activity decreased in acute exposure to $\mathrm{HgCl}_{2}$ and increased in chronic exposure to $\mathrm{HgCl}_{2}$, however, there was elevation of both AST and ALT either in acute or chronic exposure to $\mathrm{HgCl}_{2}$. Thus, ALT activity in serum, could serve as a marker enzyme to evaluate functional status of liver as suggested by Sobutskii et al. (2007). Furthermore, Jagadeesan and Pillai (2007) also reported significant increase in the level of serum AST and ALT in rats due to $\mathrm{HgCl}_{2}$ treatment for longer time period (30 days). In another study, a significant rise in the serum ALT and AST also been reported in mercury exposed rats (Singh et al. 2007).

Altogether, the present results in the light of the above cited literature clearly indicate that increase in serum ALT and AST and decrease in serum SOD and CAT, can be used as potential enzyme biomarkers for mercury-induced hepatotoxicosis and nephrotoxicois which ultimately affects the general health by altering the functional and structural integrity of liver and kidney and serve as possible bio-indicators for mercury poisoning. However, in order to establish these serums enzyme levels as biomarkers for mercury poisoning, further detailed studies are required at experimental as well as clinical levels.

\section{REFERENCES}

Abdel-Nasser M, Shaban AA, Ali SM, Manal MS. Lead, copper, Mercury and Cadmium levels in River Nile waters at some Assiut Regions, Egypt. Assiut Vet Med J. 1996; 34 (68): 95-94.

Akbar Jan F, Ishaq M, Ihsanullah I, Asim SM. Multivariate statistical analysis of heavy metals pollution in industrial area and its comparison with relatively less polluted area: A case study from the City of Peshawar and district Dir Lower. J Hazard Mater. 2010; 176: 609-616.

Anne F, Randall K, Sappington W. Framework for Metals Risk Assessment. Ecotoxicol Environ Saf. 2007; 68 (2): 145-227.
Anonymous A (2002). Neb guide, published by cooper active extension institute of Agriculture and natural resources, University of Nebraskan Lincoln.

APHA (American Public Health Association). Standard Methods for the Examination of Water and Wastewater. American Public Health Association, Washington, DC. 1995

Aradhi K, Krishna M, Satyanarayanan P, Govil K. Assessment of heavy metal pollution in water using multivariate statistical techniques in an industrial area: A case study from Patancheru, Medak District, Andhra Pradesh, India J Hazard Mat. 2009; 167: 366373.

Auger N, Kofman O, Kosatsky T, Armstrong B. Lowlevel methyl-mercury exposure as a risk factor for neurologic abnormalities in adults. Neuro Toxicol. 2005; 26: 149-157.

Bachman LJ, Krantz, DE Böhlke J. Hydro geologic Framework, Ground water, Geochemistry, and Assessment of $\mathrm{N}$ Yield from Base Flow in Two Agricultural Watersheds, Kent County, Maryland, US Environmental Protection Agency EPA/600/R02/008.2002.

Borg K. Erne K, Hanko E, Wanntorp H. Experimental secondary methyl mercury poisoning in the

Boyd AS, Seger D, Vannucci S, Langley M, Abraham JL, King LE. Mercury exposure and cutaneous disease. J Am Acad Dermatol. 2000; 43: 81-90.

Cabanero AI, Madrid Y, Camara C. Effect of animal feed enriched with $\mathrm{Se}$ and clays on $\mathrm{Hg}$ bioaccumulation in chickens: In vivo experimental study. J Agric Food Chem. 2005; 53: 2125-2132.

Chuu JJ, Liu SH, Lin-Shiau SY. Differential neurotoxic effects of methyl mercury and mercuric sulfide in rats. Toxicol Lett. 2007; 169: 109-120.

Dall Aglio M. The abundance of mercury in 300 natural water samples from Tuscany and Altium. In: Ahrens, L.H. (ed) Origin and distribution of the elements. New York Pergamon press, 1968; p. 1065.

El-Shenawy SM, Hassan NS. Comparative evaluation of the protective effect of selenium and garlic against liver and kidney damage induced by mercury chloride in the rats. Pharm Rep. 2008; 60: 199-208.

goshawk (Accipiter G. Gentilis L.). Environ Poll. 2003; 33:91-104.

Harter T, Davis H, Mathews M, Meyer R. Shallow ground water quality on dairy farms with irrigated forage crops. J Cont Hydro. 2002; 55: 287-315.

Harvey RA, Champe PC. Lippincott's Illustrated Reviews; East Washington square, Pennsylvania, 2nd ed, 1994; pp: 309 -313.

Jagadeesan G. Pillai SS. Hepatoprotective effects of taurine against mercury induced toxicity in rats. $J$ Environ Biol. 2007; 28: 753-756.

Kakkar P, Das B, Visvanathan PN. A modified spectrophotometric assay of superoxide dismutase. Ind J Biochem. 1972; 197: 588-590. 
Khan KH, Ahmad N, Sial JK, Khan MI. Ground water pollution by heavy metals. Sci Tech Dev. 1996; 14: 15.

Khan, FU, Iqbal ZS, Zaidi SH. Health hazard of trace elements in the human body. Sci Tech Dev. 1990; 9: 30-34.

Khurshid SR, Qureshi IH. The role of inorganic elements in human body. The Nucleus 1984; 21: 3-23

Kingman A, Albers JW, Arezzo JC, Garabrant TD, Michalek JE. Amalgam exposure and neurological function. Neurotoxicol. 2005; 26: 241-255.

Lund BO, Miller DM, Woods JS. Studies on Hg (II)induced $\mathrm{H}_{2} \mathrm{O}_{2}$ formation and oxidative stress in vivo and in vitro in rat kidney mitochondria. Biochem Pharmacol. 1993; 45: 2017-2024

Lysenko M. Prevention of mercury accumulation in broiler organs. Pol Inter. 2000; 11: 38-39.

Mahboob M, Shireen KF, Atkinson A, Khan AT. Lipid peroxidation and oxidant enzyme activity in different organs of mice exposed to low level of mercury. $J$ Environ Sci Health B. 2001; 36: 687-697.

Manahan SE. Toxicological chemistry, a guide to toxic substances in chemistry $2^{\text {nd }}$ ed. Macmillan Publishing Company, New York; 1989.

Mapanda F, Mangwayana EN, Nyamangara J, Giller KE. The effect of long-term irrigation using wastewater on heavy metal contents of soils under vegetables in Harare, Zimbabwe. Agric Ecosyst Environ. 2005; 107: 151-165.

Marettova E, Maretta M, Legat J, Nad P. The effect of selenium on phenyl mercury toxicity and mercury retention in chicken. Acta Vet Brno. 2003; 53: 211217.

Mohammad AH, Bhuiyan, MA, Islam, SB, Dampare L, Shigeyuki S. Evaluation of hazardous metal pollution in irrigation and drinking water systems in the vicinity of a coal mine area of northwestern Bangladesh. J Hazard Mater. 2010; 18(1): 210-221.

Pribilincov J, Marettov E, Kosutzk E. The level of mercury after application of fenylmercury in breeding hens and their offspring. Živočišn Vroba. 1997; 42: 912.

Reitman S, Frankel S. A colorimetric method for the determination of serum glutamate oxaloacetate transaminase. Amer J Clin Pathol. 1957; 28: 53-56.

Rossi LC, Santaroni MS. Mercury and Selenium distribution in a defined area and its population. Archiv Environ Healt. 1976; 31:160-165.

Saeed H M. Handed Medicos, Bait-al- Hakimah, Pakistan, Vol. XII; 1998.

Sastry KV, Sharma K. Mercury induced hematological and biochemical anomalies in Ophiocephalus (Channa) punctatus. Toxicol Lett. 1980; 5: 245-249.

Schurz FM, Sabater-Vilar T, Fink-Gremmels J. Mutagenicity of mercury chloride and mechanisms of cellular defense: The role of metal-binding proteins. Mutagen. 2000; 15: 525-530.

Seners GO, Sehirli A, Tozan A. Velioglu-Ovunc N, Gedik, T Omurtag GZ (2007). Gingko biloba extract protects against mercury (II)-induced oxidative tissue damage in rats. Food Chem Toxicol. 45: 543-550.

Sharma MK, Kumar M, Kumar A. Ocimum sanctum aqueous leaf extract provides protection against mercury induced toxicity in Swiss albino mice. Indian J Exp Biol. 2002; 40: 1079-1082.

Singh VD, Joshi S, Shrivastava T, Shukla S. Effect of monothiol along with antioxidant against mercuryinduced oxidative stress in rat. Indian J Exp Biol. 2007; 45: 1037-1044.

Smna, KA. Colorimetric assay of catalase. Anal Biochem. 1972; 47: 389-394.

Sobutskii MP, Kovanko EG, Liutinskii SI, Ivanov SD. Effect of age and gender on genotoxic and biochemical indexes in animal blood after low doses of radiation-mercury exposures. Adv Gerontol. 2007; 20: 91-96.

Timbrell, JA. Principles of Biochemical Toxicology. Taylor and Francis Ltd, London; 1982.

Wershaw RL. Sources and behavior of mercury in surface water. In: Mercury in the Environment, Washington D.C.Us. Geological survey (Professional paper No. 317); 1970.

WHO. Environmental Health Criteria 1 (Mercury). World Health Organization, Geneva; 1976.

WHO. Guide lines for drinking water quality Vol. 1 and 2 Recommendations, World Health Organization, Geneva; 1984.

WHO. Technical Report Series, No. 505 (Evaluation of certain food additives and contaminants, mercury, lead and cadmium). World Health Organization, Geneva; 1972.

WHO. Technical Report Series, No. 647 (Recommended health based limits in occupational exposure to heavy metals. World Health Organization, Geneva; 1980.

Yagi K, Rastogi R. Assay for lipid peroxides in animal tissues thiobarbituric acid reaction. Anal Biochem. 1979; 95: 351-358.

Youssef AE Haleem HH. Estimation of some heavy metals in polluted and unpolluted areas and their relation to certain reproduction disorders in buffalocows, Beni-Suef .Vet Med J. 1999; IX (2): 109-124.

Zaki ZM, Abdel-Nasser M, Nagwa ME, Saddek AS. Toxicological elements in different water sources in Assiut Governorate and possible health risk. Bull Fac Sci, Assiut Univ. 1994; 23 (1): 225-241.

Zral Z, Sařkov BP, Navrtilov M.The effect of humic acid on mercury accumulation in chicken organs and muscle tissues. Czech J Anim Sci. 2008; 53(11): 472477.

Received: March 29, 2012; Accepted: January 20, 2013. 